Araştırma Makalesi
Adıaman Üniversitesi
Mühendislik Bilimleri Dergisi
$15(2021) 525-534$

\title{
INVESTIGATION OF THERMO-HYDRAULIC PERFORMANCE OF NANOFLUIDS IN A ZIGZAG CHANNEL WITH BAFFLES
}

\author{
Selma AKÇAY ${ }^{*}$ \\ ${ }^{1}$ Cankiri Karatekin University, Engineering Faculty, Department of Mechanical Engineering, Cankiri, 18100, Turkey \\ Geliş Tarihi/Received Date: 24.09.2021 Kabul Tarihi/Accepted Date: 08.12.2021 DOI: 10.54365/adyumbd.1000525
}

\begin{abstract}
In this study, the thermo-hydraulic performance of $\mathrm{Al}_{2} \mathrm{O}_{3}$-water nanofluid in a zigzag channel with baffles were numerically investigated. The mass, momentum and energy equations are discretized with finite volume approach and iterations are solved with SIMPLE algorithm. Reynolds number $(200 \leq \mathrm{Re} \leq 1600)$, and nanoparticle volume fraction $(0.01 \leq \varphi \leq 0.03)$ were changed, and other parameters kept constant. The lower and upper zigzag surfaces of the channel were kept at constant temperature, and the Nusselt number and friction factor along the channel were calculated. The velocity and temperature contours in the channel were obtained in order to observe the effects of the parameters on the flow and heat transfer. The results shown that the increasing particle volume fractions and Reynolds numbers improved the heat transfer, while the friction factor increased slightly. The best thermo-hydraulic performance was obtained at $\operatorname{Re}=1400$ and $\varphi=3 \%$ as approximately 1.15 .
\end{abstract}

Keywords: Nanofluid, Baffle, Zigzag channel, Heat transfer, Thermo-hydraulic performance

\section{İÇERISSINDE BÖLMELER BULUNAN ZIGGZAG BİR KANALDA NANOAKIŞKANLARIN TERMO-HIDROLIKK PERFORMANSININ INCELENMESI}

\section{ÖZET}

$\mathrm{Bu}$ çalışmada, içerisinde bölmeler bulunan zigzag bir kanalda $\mathrm{Al}_{2} \mathrm{O}_{3}$-su nanoakışkanın termo-hidrolik performansı sayısal olarak incelenmiştir. Kütle, momentum ve enerji eşitlikleri sonlu hacim yöntemi ile ayrıklaştırılmış ve iterasyonlar SIMPLE algoritması ile çözülmüştür. Reynolds sayısı $(200 \leq \operatorname{Re} \leq 1600)$ ve partikül hacim oranı $(0.01 \leq \varphi \leq 0.03)$ değiştirilmiş ve diğer parametreler sabit tutulmuştur. Zigzag kanalın alt ve üst yüzeyleri sabit sıcaklıkta tutulmuş ve kanal boyunca Nusselt sayısı ve sürtünme faktörü hesaplanmıştır. Parametrelerin, akış ve 1sı transferi üzerindeki etkilerini gözlemlemek için kanal içerisinde hız ve sicaklık görüntüleri elde edilmiştir. Sonuçlar, artan partikül hacim oranları ve Reynolds sayıları ile 1sı transferinin iyileştiğini, sürtünme faktörünün hafif şekilde arttığını göstermiştir. En iyi termo-hidrolik performans $R e=1400$ ve $\varphi=\% 3$ 'de yaklaşık 1.15 olarak elde edilmiştir.

Anahtar Kelimeler: Nanoakışkan, Bölme, Zigzag kanal, Isı transferi, Termo-hidrolik performans

\section{Introduction}

In engineering applications, heat transfer improvement is an important research area as it contributes to the efficiency of thermal devices. Passive and active methods are widely used to increase heat transfer without reducing the overall efficiency of these devices. Passive methods are applications such as in-channel baffles, bent band, vortex generators and special surface geometries. These applications, which do not require an external power, are preferred in evaporators, condensers, gas turbine cooling, nuclear reactors, heat exchangers, solar air heaters. This method is economical

\footnotetext{
*1 e-mail: selma.352@,hotmail.com ORCID ID: https://orcid.org/0000-0003-2654-0702
} 
and reliable compared to other techniques as it has no moving parts and does not require any external energy [1-8]. Promvonge et al. [9] experimentally investigated the heat transfer performance in a channel where inclined horseshoe baffles were used and reported that the heat transfer increased by approximately $92-208 \%$ and the friction factor increased by 1.76-6.37 compared to straight channels. Kumar et al. [10] experimentally studied the heat transfer behavior of the solar air channel using multiple V-type baffles. Sahel et al. [11] reported that the different baffle design in a rectangular channel improved heat transfer by 65\%. Dagdevir et al. [12] numerically examined flow and thermal behaviors in a horizontal tube having trapezoidal dimples with different geometric parameters for both transient and turbulent flow regime. They reported that numerical results were highly influenced by geometric parameters.

In order to improve heat transfer, corrugated channels of different geometries have been studied experimentally and numerically by many researchers. The corrugated surfaces have a significant effect on heat transfer enhancemet as they both increase the surface area and provide self-flow oscillation, but these channels increase the pressure drop compared to straight channels [13-17].

Fluids containing water, ethylene glycol, and oil, widely used in industrial applications, have low thermal properties. New technologies are used to improve the thermo-physical properties of such conventional coolants. One of these techniques is the addition of nano-sized solid particles with high thermal conductivity to the base fluid. Some researchers have used nanofluids together with other passive techniques [18-20]. Manca et al. [21] examined the heat transfer for the $20000 \leq \operatorname{Re} \leq 60000$ of $\mathrm{Al}_{2} \mathrm{O}_{3}$-water nanofluid at different rib heights, at $0 \%$ to $4 \%$ nanoparticle volume ratios in a channel where homogeneous heat flux was applied to the walls. As a result, they reported that as the Reynolds number and particle volume ratio increased, the heat transfer improved and at the same time an increase in the pumping power was observed. Heshmati et al. [22] numerically studied the mixed convective heat transfer in the $50 \leq \mathrm{Re} \leq 400$ with the baffles of different geometries at varying particle volume fractions $(0.01 \leq \phi \leq 0.04)$ of different nanofluids. As a result, they reported that the nanofluids with hight particle volume fractions and small nanoparticle diameter significantly improved heat transfer. Ajeel et al. [23] numerically studied the flow and heat transfer properties of ZnO-water nanofluid for turbulent flow with L-shaped baffles in a curved corrugated channel and reported that baffles and nanofluids increased heat transfer. Menni et al. [24] carried out the dynamic and thermal behaviors of nanofluids in turbulent flow conditions by using baffles at different angles in a channel and reported that the highest thermal improvement was obtained when vertical baffles were used at high Reynolds numbers. Keklikcioglu and Ozceyhan [25] experimentally investigated the effects of combined using of water-graphene nanoplatelet nanofluid and three different conical wire coils on thermohydraulic performance of a heat exchanger tube. As a result, they declared that use of conical wire coils caused to increase both the heat transfer and fluid friction, also adding the graphene nanoplatelet in water led to strongly increase in heat transfer with a slight increase in friction factor.

There are many studies in the literature examining the combined effects of passive heat transfer applications. However, the high number of parameters used has increased the efforts to find the optimum parameters and new studies are needed on this subject. Previous studies have focused on different baffle arrangements in straight channels. The effects of vertical baffle on flow and heat transfer of the nanofluids in a zigzag corrugated channel have not been investigated. In order to fill this gap in the literature studies, the presented channel geometry was used. Therefore, in this study, the effects on heat transfer and friction factor of $\mathrm{Al}_{2} \mathrm{O}_{3}$-water nanofluid in a zigzag channel with baffles was numerically investigated. $\mathrm{Al}_{2} \mathrm{O}_{3}$ nanoparticles are widely used in literature studies $[14,18,21,26]$. $\mathrm{Al}_{2} \mathrm{O}_{3}$ nanoparticle was preferred in the study because it is both cheaper and easier to find than other nanoparticles.

\section{Numerical Study}

The geometry of the zigzag channel with baffle is given in Figure 1. The numerical model is considered as two dimensional. The height of the channel $(\mathrm{H})$ is $19 \mathrm{~mm}$. At the entrance and exit of 
the channel, the lengths of unheated flat section are $\mathrm{L}_{1}=11 \mathrm{H}$. The total length of the zigzag channel with baffles is $\mathrm{L}_{2}=12 \mathrm{H}$. The length of zigzag section is considered as $\mathrm{S}=1.5 \mathrm{H}$ and the thickness as $\mathrm{t}$ $=3 \mathrm{~mm}$. The baffle lengths are $t_{2}=6 \mathrm{~mm}, \mathrm{t}=3 \mathrm{~mm}$ and the thickness of the baffles is $\mathrm{t}_{1}=0.5 \mathrm{~mm}$. Other geometric parameters were kept constant.

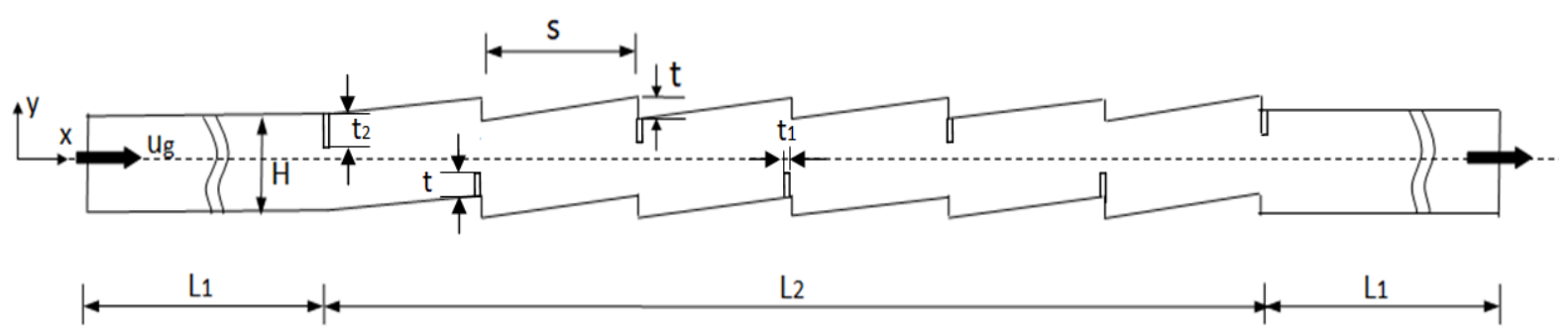

Figure 1. Geometry of the numerical model.

$\mathrm{Al}_{2} \mathrm{O}_{3}$-water suspension was considered as the nanofluid, and three different nanoparticle volume fractions $(\varphi=1 \%, 2 \%$ and $3 \%)$ were used. The simulations were applied for $200 \leq \operatorname{Re} \leq 1600$. This study was carried out in laminar flow regime. In order to avoid the critical Reynolds number for internal flows, the highest Reynolds number studied was accepted as $R e=1600$. The flow in the channel was considered to be fully developed, laminar, incompressible, two-dimensional, steady, Newtonian type and single-phase. The heat transfer with gravity and radiation has been neglected. The governing equations for these assumptions are given below;

$$
\begin{aligned}
& \frac{\partial u_{i}}{\partial t}+\nabla(\rho u)=0 \\
& \frac{\partial u_{i}}{\partial t}+\frac{\partial\left(u_{i} u_{j}\right)}{\partial x_{i}}=-\frac{\partial p}{\partial x_{i}}+\frac{1}{\operatorname{Re}} \nabla^{2} u_{j} \\
& \frac{\partial T}{\partial t}+u_{i} \frac{\partial T}{\partial x_{i}}=\frac{1}{\operatorname{RePr}} \nabla^{2} T
\end{aligned}
$$

Computational Fluid Dynamics (CFD) based FLUENT 15.0 [27] program was used for numerical solutions. The equations were solved using the SIMPLE algorithm and the convection and diffusion terms were discriminated using a second order upwind scheme. The convergence criterion was taken as $10^{-6}$ for all residuals. Pave type triangular elements were used in the mesh structure of the numerical model. The mesh spacing was chosen as 0.38. The mesh structure including the three zigzag sections of the channel was shown in Figure 2. Various tests were applied for grid independence at cell numbers of 15785, 38624, 55346, 76409, 98114, 122793. After 76409 element numbers, the difference between Nusselt numbers was determined to be less than $2 \%$. Therefore, the element number of 76409 was adopted for the numerical model. The variation of element numbers and Nusselt numbers were given in Table 1 and Figure 3.

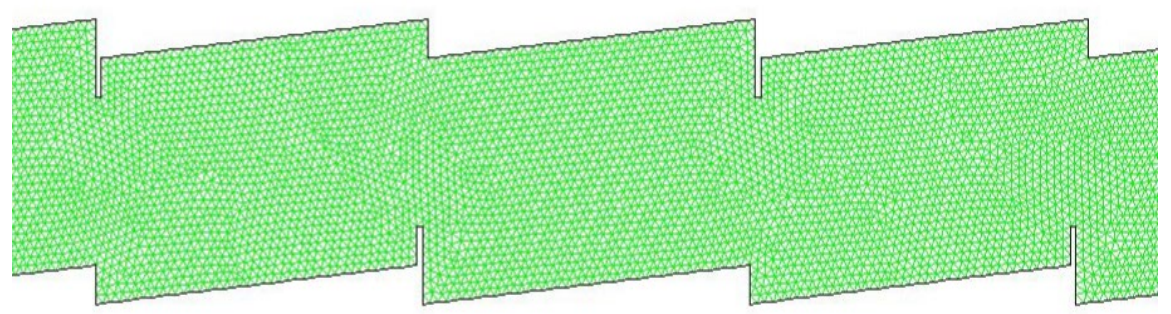

Figure 2. The mesh structure of the numerical model. 
Table 1. The Results of Grid Independence Test. ( $\mathrm{Re}=200$ and $\mathrm{Re}=800$, for base fluid)

\begin{tabular}{cccc}
\hline Grid name & Number of elements & $\begin{array}{c}\text { Nusselt Number } \\
\mathrm{Re}=200\end{array}$ & $\begin{array}{c}\text { Nusselt Number } \\
\mathrm{Re}=800\end{array}$ \\
\hline G1 & 15785 & 2,506 & 6,853 \\
G2 & 38624 & 3,367 & 7,641 \\
G3 & 55346 & 4,095 & 8,403 \\
G4 & 76409 & 4,362 & 8,697 \\
G5 & 98114 & 4,413 & 8,716 \\
G6 & 122793 & 4,415 & 8,721 \\
\hline
\end{tabular}

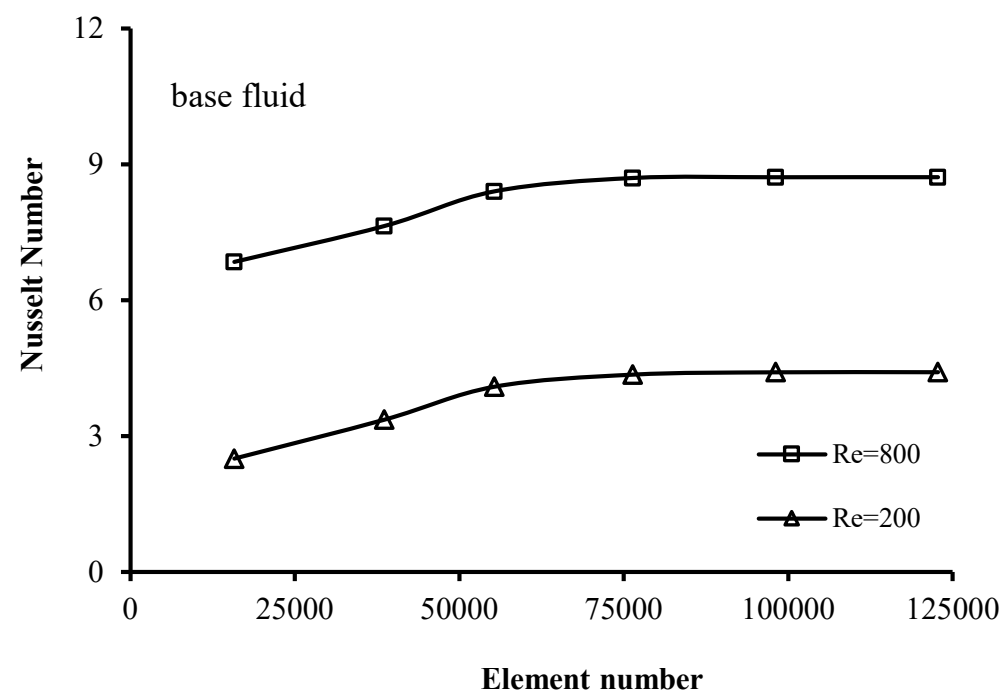

Figure 3. Grid independence testing for $\mathrm{Re}=200$ and $\mathrm{Re}=800$ (for base fluid).

The thermo-physical properties of nanofluids were obtained as follow (density by Eq. (4) and specific heat by Eq. (5) [28], thermal conductivity by Eq. (6) and viscosity by Eq. (7) [29].)

$$
\begin{aligned}
& \rho_{n f}=(1-\varphi) \rho_{b f}+\varphi \rho_{p t} \\
& c_{n f}=(1-\varphi) c_{b f}+\varphi c_{p t} \\
& k_{n f}=k_{b f} \frac{\left[k_{p t}+2 k_{b f}-2 \varphi\left(k_{b f}-k_{p t}\right)\right]}{\left[k_{p t}+2 k_{b f}+\varphi\left(k_{b f}-k_{p t}\right)\right]} \\
& \mu_{n f}=\mu_{b f}\left(123 \varphi^{2}+7.3 \varphi+1\right)
\end{aligned}
$$

The water was used as the base fluid. Thermo-physical properties of $\mathrm{Al}_{2} \mathrm{O}_{3}$ nanoparticle and water were given in Table 2.

Table 2. Thermo-physical Properties of $\mathrm{Al}_{2} \mathrm{O}_{3}$ Nanoparticle and Water

\begin{tabular}{ccccc}
\hline & $\rho\left[\mathrm{kg} / \mathrm{m}^{3}\right]$ & $\mathrm{c}[\mathrm{j} / \mathrm{kgK}]$ & $\mathrm{k}[\mathrm{W} / \mathrm{mK}]$ & $\mu[\mathrm{kg} / \mathrm{ms}]$ \\
\hline water & 998 & 4182 & 0.613 & 0.001003 \\
$\mathrm{Al}_{2} \mathrm{O}_{3}$ & 3970 & 765 & 37 & - \\
\hline
\end{tabular}

The fluid temperature at the channel inlet is $T_{0}=293 \mathrm{~K}$. At the channel entrance, the "velocity inlet" boundary condition was defined. The flow was considered as fully developed flow at the outlet 
because the straight section at the channel outlet was long enough compared to the channel diameter. At the outlet of the channel, "outflow" boundary condition was applied. The lower and upper surfaces of the zigzag channel were preserved at a constant temperature of $T_{w}=340 \mathrm{~K}$ and non-slip boundary condition for the channel walls was defined. A non-slip and adiabatic boundary conditions were applied for the straight section at the entrance and exit of the channel.

\section{Results and Discussion}

For the validation of the numerical solutions, present study was compared with the experimental results of Meyer and Abolarin [30]. A straight channel with a diameter of $19 \mathrm{~mm}$ was used and a constant heat flux of $2 \mathrm{~kW}$ was applied to the channel surfaces. The heat transfer coefficient was calculated with $\mathrm{x} / \mathrm{D}$ distances along the channel for $\mathrm{Re}=1331$. The agreement between the results of both studies was shown in Figure 4.

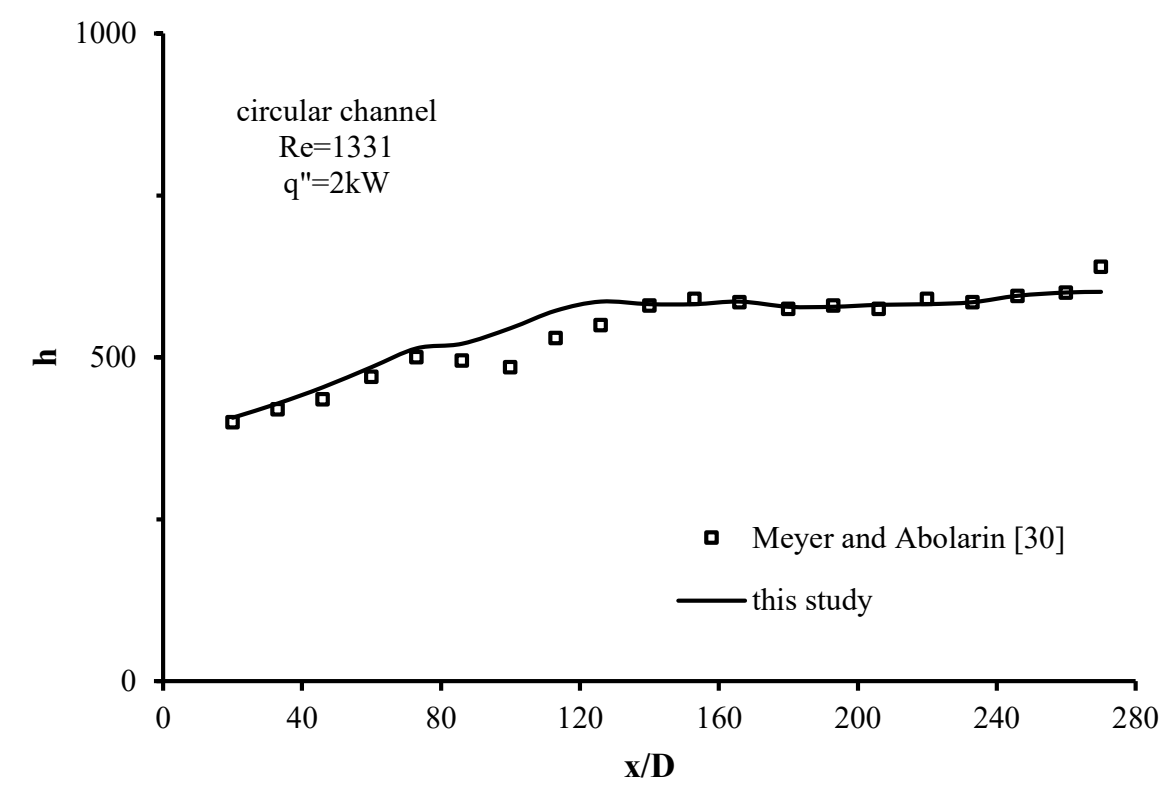

Figure 4. The validation of the numerical solution.

In this section, the velocity, temperature and vortex structures were obtained in the channel to explain the flow and heat transfer mechanism. In Figure 5, the velocity, temperature, and vortex structures were given for $\mathrm{Re}=200$ (Fig.5a) and $\mathrm{Re}=1600$ (Fig.5b) at a constant particle volume fraction $(\varphi=0.02)$. It can be seen that the structure of the zigzag channel with baffles significantly affected the flow and temperature fields depending on the Reynolds number. It was shown that the channel geometry caused flow oscillation. As the inlet velocity of the fluid increases, the flow separations occur within the channel.

The baffles help reduce thermal resistance by disrupting the laminar layer on the channel surfaces. In addition, the baffles caused the formation of secondary flow structures in the channel. Increasing Reynolds numbers created larger flow cycles. Thus, heat transfer improved by better contacting the cold fluid with the hot fluid in the channel surfaces.

In Figure 6, the velocity structures (Fig. 6a) and temperature structures (Fig. 6b) were given for $\mathrm{Re}=1400$ at different particle volume fractions. The particle volume fraction was not significantly change the flow structure, but it was seen that the temperature in the channel surfaces decreased with the increase of the particle volume fraction. 


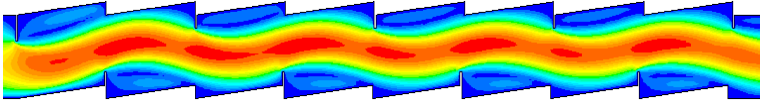

$\operatorname{Re}=200, \varphi=0.02$, velocity contour

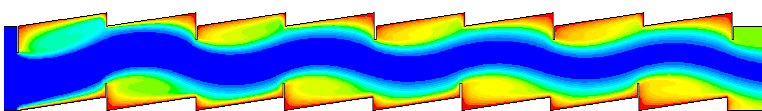

$\operatorname{Re}=200, \varphi=0.02$, temperature contour

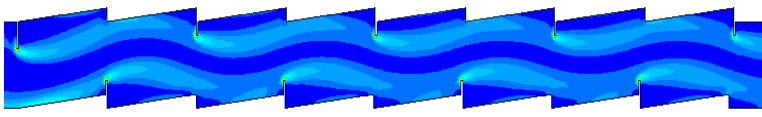

$\operatorname{Re}=200, \varphi=0.02$, vorticity contour

a

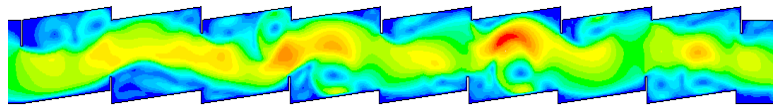

$\operatorname{Re}=1600, \varphi=0.02$, velocity contour

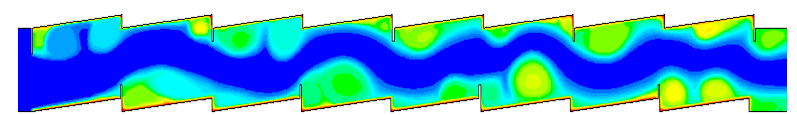

$\operatorname{Re}=1600, \varphi=0.02$, temperature contour

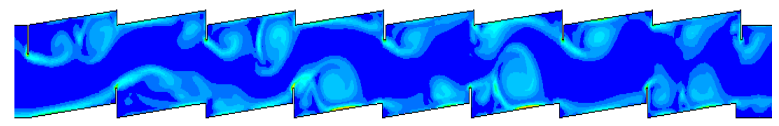

$\operatorname{Re}=1600, \varphi=0.02$, vorticity contour

b

Figure 5. The velocity, temperature and vortex structures at a constant particle volume fraction $(\varphi=0.02), a-\operatorname{Re}=200, b-\operatorname{Re}=1600$.

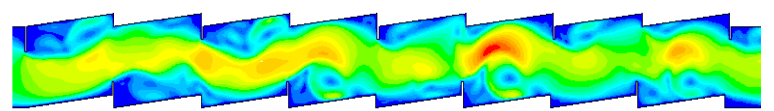

$\operatorname{Re}=1400, \varphi=0.01$

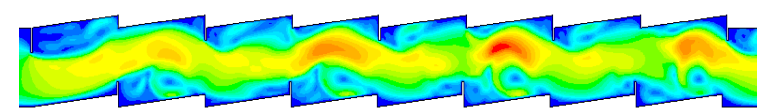

$\operatorname{Re}=1400, \varphi=0.02$

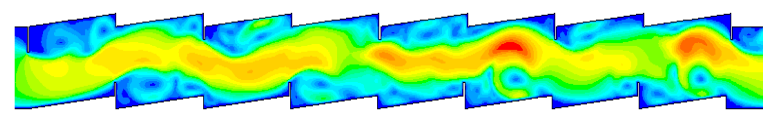

$\operatorname{Re}=1400, \varphi=0.03$

a

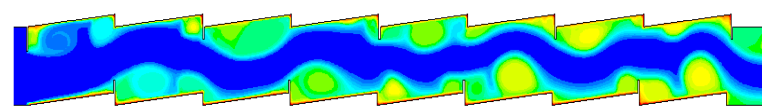

$\operatorname{Re}=1400, \varphi=0.01$

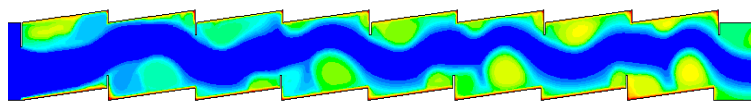

$\operatorname{Re}=1400, \varphi=0.02$

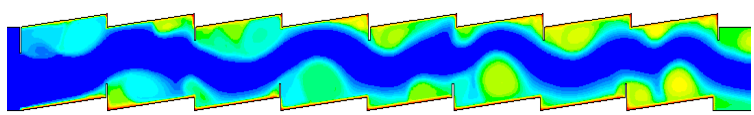

$\operatorname{Re}=1400, \varphi=0.03$

b

Figure 6. a-The velocity structures $b$ - The temperature structures at $\mathrm{Re}=1400$ for different nanoparticle volume fractions.

In this study, Nusselt numbers are defined by Equations (8-9) to calculate the local and average heat transfer in the channel:

$$
\begin{aligned}
& N u_{x}=\frac{q^{\prime \prime} D_{h}}{k\left(T_{w, x}-T_{b, x}\right)} \\
& N u=\frac{1}{L} \int_{0}^{L} N u_{x} d x
\end{aligned}
$$

where, $\mathrm{k}$ is the thermal conductivity coefficient of the nanofluid, $\mathrm{D}_{\mathrm{h}}$ is the hydraulic diameter of the channel, $\mathrm{L}$ is the total channel length, $\mathrm{T}_{\mathrm{w}}$ is the surface temperature of the channel. The film temperature of the nanofluid is calculated as $T_{b}=\left(T_{\text {in }}+T_{\text {out }}\right) / 2$.

The heat transfer performance calculated based on the Nusselt number is defined as $\eta$ and shown by Equation (10). 


$$
\eta=\frac{N u_{n}}{N u_{s}}
$$

where, $\mathrm{Nu}_{\mathrm{n}}$ is the average Nusselt number calculated for the nanofluid, and $\mathrm{Nu}_{\mathrm{s}}$ is the Nusselt number calculated for the base fluid.

On the other hand, depending on the particle volume fraction and fluid velocity, a significant pressure drop occurs in the wall and fluid. Due to the high viscosity of nanofluids compared to the base fluid, the pressure drop should also be evaluated in heat transfer improvement studies. In the study, the dimensionless friction factor $r=f_{n} / f_{s}$ is defined to determine the pressure drop of the nanofluid. Where, $f_{n}$ shows the surface friction for the nanofluid flow and $f_{s}$ is the surface friction for the base flow. Thermo hydraulic performance is achieved by the ratio of heat transfer performance to friction factor and is defined by Eq. (11):

$$
T H P=\frac{\left(N u_{n} / N u_{s}\right)}{\left(f_{n} / f_{s}\right)^{1 / 3}}
$$

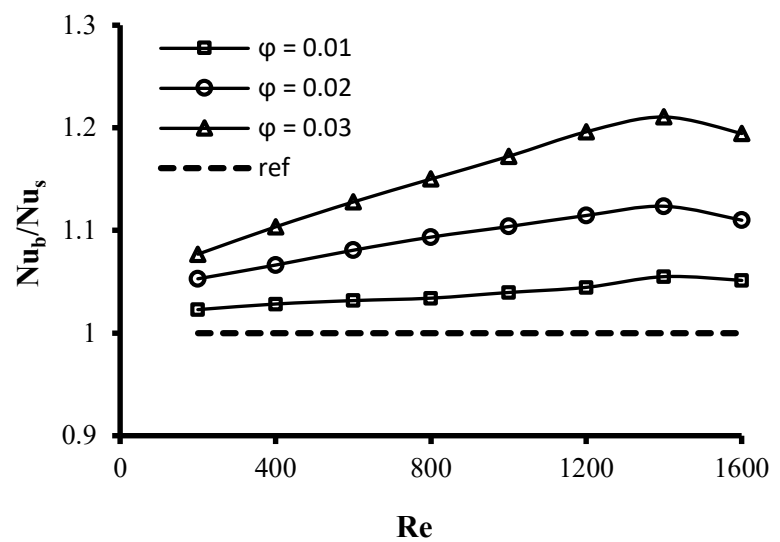

$\mathbf{a}$

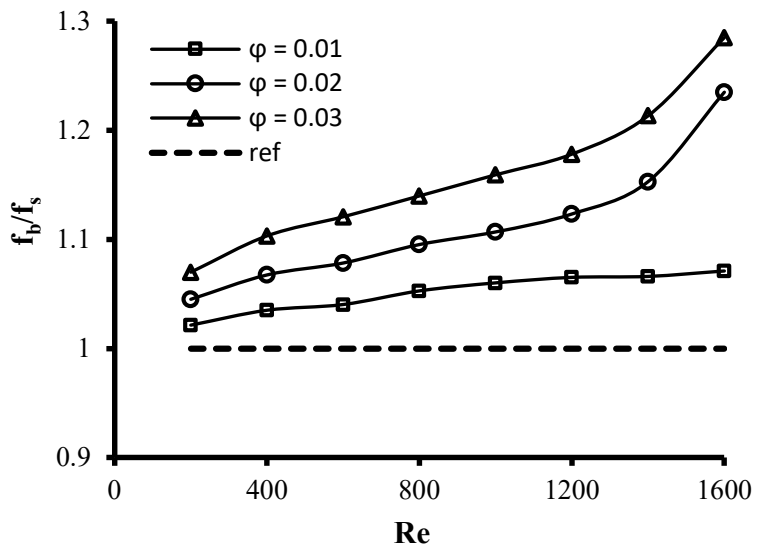

b

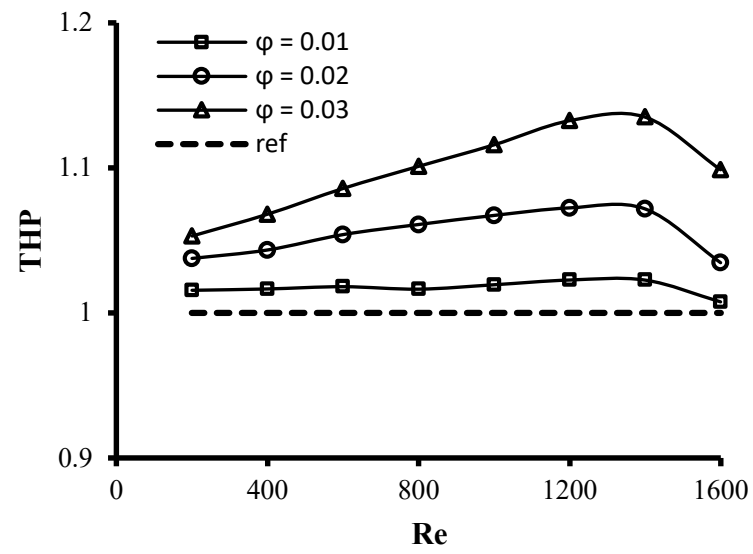

c

Figure 7. a-The heat transfer performance, b- The dimensionless friction factor, c- Thermo-hydraulic performance, at different Reynolds numbers ve particle volume fractions.

The variation of the heat transfer performance with Reynolds number for different particle volume fractions in Figure 7a, the dimensionless friction factor in Figure 7b, and the thermo-hydraulic performance in Figure 7c were given. From these figures, it was seen that the heat transfer 
performance and friction factor increased with the increase of particle volume fraction and Reynolds number. The dashed line represents the base fluid for the same geometry. The frictions increased with the effect of the baffles in zigzag channel and the increase in the particle volume fraction. There is a slight downward trend in heat transfer performance at $\mathrm{Re}=1600$. For $\varphi=0.03$, this decrease is more pronounced than the others. The reason for this can be evaluated as the increase in the density of the fluid with the high particle volume ratio and the decrease in the flow velocity.

The highest heat transfer performance was obtained as $\eta=1.21$ at $\operatorname{Re}=1400$ and $\varphi=0.03$. The baffles and nanofluids in the zigzag channel provided significantly heat transfer improvement, while an acceptable increase in friction factor was observed. The highest friction factor was found to be $\mathrm{r}=1.28$ at $\mathrm{Re}=1600$ and $\varphi=0.03$. In Figure $7 \mathrm{c}$, Thermo-hydraulic performance values were obtained above the reference value for all Reynolds numbers and particle volume fractions because the heat transfer improvement was greater than the frictions in the channel. At $R e=1600$, the THP curve shows a sharp decline. This is because the friction inside the channel is greater than the heat transfer improvement. The highest thermo-hydraulic performance was obtained at $\varphi=0.03$ and $\operatorname{Re}=1400$ as approximately $\mathrm{THP}=1.15$.

\section{Conclusions}

In this study, the effects on the flow and heat transfer of $\mathrm{Al}_{2} \mathrm{O}_{3}$-water nanofluid in a zigzag channel with baffles were numerically investigated. The effects of particle volume fraction and Reynolds number on the flow and heat transfer were analyzed. The results obtained in the study are listed below:

a. The flow and temperature fields are highly influenced by channel geometry.

b. The secondary flow structures in the channel increase with the increase of the inlet velocity.

c. The particle volume fraction has an important role in heat transfer improvement under laminar steady flow conditions.

d. The heat transfer performance increases with the increase of Reynolds number and particle volume fraction, and friction factor increases slightly.

e. The best thermo-hydraulic performance is obtained as approximately THP $=1.15$ at $\operatorname{Re}=$ 1400 and $\varphi=0.03$.

\section{References}

[1] Lei YG, He YL, Li R, Gao YF. Effects of baffle inclination angle on flow and heat transfer of a heat exchanger with helical baffles. Chem. Eng. Process 2008; 47(12): 2336-2345.

[2] Keklikcioglu O, Ozceyhan V. Experimental investigation on heat transfer enhancement of a tube with coiled-wire inserts installed with a separation from the tube wall. International Communications in Heat and Mass Transfer 2016; 78. 88-94.

[3] Nanan K, Piriyarungrod N, Thianpong C, Wongcharee K, Eiamsa-ard S. Numerical and experimental investigations of heat transfer enhancement in circular tubes with transverse twisted-baffles. Heat Mass Transfer 2016; 52: 2177-2192.

[4] Li Z, Gao Y. Numerical study of turbulent flow and heat transfer in cross corrugated triangular ducts with delta-shaped baffles. Int. J. Heat Mass Transfer 2017; 108: 658-670.

[5] Sriromreun P. Numerical study on heat transfer enhancement in a rectangular duct with incline shaped baffles. Chem. Eng. Transfer 2017; 57: 1243-1248.

[6] Rashidi S, Eskandarian M, Mahian O, Poncet S. Combination of nanofluid and inserts for heat transfer enhancement, Gaps and challenges. Journal of Thermal Analysis and Calorimetry 2019; 135: 437-460. 
[7] Alnak DE. Thermohydraulic performance study of different square baffle angles in crosscorrugated channel. Journal of Energy Storage 2020; 28: 101295.

[8] Chang SW, Cheng TH. Thermal performance of channel flow with detached and attached pin-fins of hybrid shapes under inlet flow pulsation. International Journal of Heat and Mass Transfer 2021; 164: 120554.

[9] Promvonge P, Tamna S, Pimsarn M, Thianpong C. Thermal characterization in a circular tube fitted with inclined horseshoe baffles. Appl. Therm. Eng. 2015; 75: 1147-1155.

[10] Kumar R, Kumar A, Chauhan R, Sethi M. Heat transfer enhancement in solar air channel with broken multiple V-type baffle. Case Stud. Therm. Eng. 2016; 8: 187-197.

[11] Sahel D, Ameur H, Benzeguir R, Kamla Y. Enhancement of heat transfer in a rectangular channel with perforated baffles. Appl. Therm. Eng. 2016; 101: 156-164.

[12] Dagdevir T, Keklikcioğlu O, Ozceyhan V. Heat transfer performance and flow characteristic in enhanced tube with the trapezoidal dimples. International Communications in Heat and Mass Transfer 2019; 108: 104299.

[13] Akdag U, Akcay S, Demiral D. Heat transfer enhancement with nanofluids under laminar pulsating flow in a trapezoidal-corrugated channel, Progress in Computational Fluid Dynamics, An International Journal 2017; 17(5): 302-312.

[14] Akdag U, Akcay S, Demiral D. Heat transfer enhancement with laminar pulsating nanofluid flow in a wavy channel. International Communications in Heat and Mass Transfer 2014; 59: 17-23.

[15] Akcay S, Akdag U. Parametric investigation of effect on heat transfer of pulsating flow of nanofluids in a tube using circular rings. Pamukkale University, Journal of Engineering Sciences 2018; 24(4): 597-604.

[16] Akdag U, Akcay S, Demiral D. Heat transfer in a triangular wavy channel with CuO-water nanofluids under pulsating flow. Thermal Science 2019; 23(1):191-205.

[17] Davletshin IA, Mikheev AN, Mikheev NI, Shakirov RR. Heat transfer and structure of pulsating flow behind a rib. Int.Jour.Heat and Mass Transfer 2020; 160: 120173.

[18] Chandrasekar M, Suresh S, Bose AC. Experimental studies on heat transfer and friction factor characteristics of $\mathrm{Al}_{2} \mathrm{O}_{3}$ /water nanofluid in a circular pipe under laminar flow with wire coil inserts. Exp Therm Fluid Sci. 2010; 34(2): 122-130.

[19] Fazeli H, Madani S, Mashaei PR. Nanofluid forced convectionin entrance region of a baffled channel considering nanoparticle migration. Appl Therm. Eng. 2016; 106: 293-306.

[20] Karouei SHH, Ajarostaghi SSM, Gorji-Bandpy M, Fard SRH. Laminar heat transfer and fluid flow of two various hybrid nanofuids in a helical double-pipe heat exchanger equipped with an innovative curved conical turbulator. Journal of Thermal Analysis and Calorimetry 2021; 143: $1455-1466$.

[21] Manca O, Nardini S, Ricci D. A numerical study of nanofluid forced convection in ribbed channels. Applied Thermal Engineering 2012; 37: 280-297.

[22] Heshmati A, Mohammed HA, Darus AN. Mixed convection heat transfer of nanofluids over backward facing step having a slotted baffle. Applied Mathematics and Computation 2014; 240: $368-386$.

[23] Ajeel RK, Sopian K, Zulkifli R. Thermal-hydraulic performance and design parameters in acurved-corrugated channel with L-shaped baffles and nanofluid. Journal of Energy Storage 2021; 34: 101996.

[24] Menni Y, Chamkha AJ, Ghazvini M, Ahmadi MH, Ameur H, Issakhov A, Inc M. Enhancement of the turbulent convective heat transfer in channels through the baffling technique and oil/multi walled carbon nanotube nanofluids. Numerical Heat Transfer, Part A: Applications 2021; 79(4): 311-351.

[25] Keklikcioğlu O, Ozceyhan V. Thermohydraulic performance evaluation for horizontal tube by using combination of modified coiled wire inserts and graphene nanoplatelet-water nanofluids. International Communications in Heat and Mass Transfer 2021; 123: 105206.

[26] Tian MW, Khorasani S, Moria H, Pourhedayat S, Dizaji HS. Profit and efficiency boost of triangular vortex-generators by novel techniques. Int. Journal of Heat and Mass Transfer 2020; 156: 119842 . 
[27] ANSYS. Fluent user guide \& theory guide- (Release 15. 0) Fluent Ansys Inc., USA, 2015.

[28] Pak B, Cho YI. Hydrodynamic and heat transfer study of dispersed fluids with submicron metallic oxide particles. Experimental Heat Transfer 1998; 11(2): 151-170.

[29] Kakac S, Pramuanjaroenkij A. Review of convective heat transfer enhancement with nanofluids. Int. Jour. Heat and Mass Transfer 2009; 52: 3187-3196.

[30] Meyer JP, Abolarin SM. Heat transfer and pressure drop in the transitional flow regime for a smooth circular tube with twisted tape inserts and a square-edged inlet. Int. Jour. Heat and Mass Transfer 2018; 117: 11-29. 